\title{
Is Transhumanism Heading Towards Redefinition of Human Being or Towards Utopia?
}

\author{
RAFAŁ SZOPA \\ Wroclaw University of Science and Technology \\ rafal.szopa@pwr.edu.pl \\ ORCID: 0000-0002-6977-3103
}

\begin{abstract}
Transhumanism has enormous affect on temporary philosophical thought by forcing philosophers to take on many intellectual challenges generated by scientists who try to create technological solutions that enable implementation of transhumanistic ideas. The question is whether all these ideas will be realized. The purpose of the article is to show that the ulitmate goal of transhumanism, to create posthumanistic society, is impossible to realize. The first reason is that transhumanism limits human's understanding to the material dimension (from a theological viewpint). While this is understandable in the naturalistic paradigm, this approach is insufficient when it comes to all complexity of human being and for this reason transhumanism represents too narrow a human's understanding to be able to implement its all assumptions. The second reason is that to enable people to become posthumans the latest technologies would have to be available to everyone and this seems impossible. If so, such a situation will divide people into ordinary ones and posthumans and this could lead to conflicts that transhumanists want to avoid after all. Finally, the body-mind problem is essentially limited to emergentism, which corresponds to the naturalistic paradigm. It seems, however, that without the concept of the soul it is impossible to understand who a man is, their identity and consciousness and this is crucial for mind uploading.
\end{abstract}

Keywords: evolution; soul; cryonics; mind uploading. 


\section{Introduction}

Transhumanism seems to be much more than only an attempt to improve human life. The key concept regarding transhumanism is enhancement. What does it really mean to enhance human nature? Is human nature enhanceable? And, the final question: will enhancement entail the necessity to redefine human nature and to formulate another definition of human? On the answers for these questions depend the implementation of transhumanistic idea or it will pertain to Utopian attitudes when it comes to creating the best social system being composed of posthumans having extraordinary capabilities so advanced that they will be another genus. I do not want to present transhumanism as such but basing on some transhumanistic ideas I will show arguments indicating whether transhumanism is possible or not to realize.

\section{Understanding of a human being in transhumanism}

Let us start with possible attitudes to a human being. Basically there are three conception of human/humanity: 1) a man is "a product" of the natural selection process completely described by the theory of evolution; 2) a man is contingent being of two elements: body and soul; 3) a man is an embodied soul - Plato's attitude. The third option is rather unpopular or just outdated among the vast majority of philosophers. But it does not mean that the term like "soul" is outdated too. It depends on a paradigm we accept to say whether the usage of the term "soul" is justified or not. It does not change the fact that the term is used. If transhumanism is based on a certain conception of human, it is the first one. The arguments for a such statements can be taken from Max Moore's A Letter to Mother Nature. He writes: "[...] you have in many ways done a poor job with the human constitution" (Moore 2009; cf. Asla 2019, 90-91: a poor job is done by the original sin and loss of grace). So, what is the human constitution? Generally speaking it is narrowed down to the nature: "You made us functional only under narrow environmental conditions” (Moore, 2009). A human being 
is completely describable and explicable by the theory of evolution. Such attitude enables transhumanism to hope that the human nature can be changed by technology. If this assumption regarding our nature is sine qua non condition for transhumanism, let us see what entails thinking about humans as the result of the natural selection process only.

The theory of natural selection has two authors: Charles Darwin and Alfred Wallace. They both agreed with one another on natural selection but disagreed with human evolution (Glickaman 2009, 33). Wallace invoked "Power" and "Higher Intelligence" to show the origin of the mankind (Ibid.). Their ways split. Darwin was faithful to the naturalistic paradigm but his "discussion of human evolution in The Origin of Species is very limited" (Ibid., 35). This gap was filled in by Wallace, who believed that the mind gave us advantage over other species but finally rejected natural selection in 1869 "as the sole element involved in the genesis of humanity" (Ibid., 35-36). He enumerated a few characteristics testifying about another origin than the natural selection, like "hairlessness, the structure of human hand and the vocal power of larynx" (Ibid., 36), because the ones "could not have contributed to survival and reproduction and therefore could not be selected" (Ibid.). But the most problematic issue is the brain.

According to Wallace our brains are so good developed, despite the needs people have, that it does not come from natural selection. He compared different peoples living on Earth - unlearned and learned societies (Europeans) - and concluded that we all possess brains having abilities far beyond our needs letting us to survive: "How, then, was an organ developed so far beyond the needs of its possessor? Natural selection could only have endowed the savage with a brain a little superior to that of an ape, whereas he actually possesses one but very little inferior to that of the average members of our learned societies" (Wallace 1869, 392). Darwin denied Wallace's attitude and encapsulated his theory in the naturalistic paradigm. Darwin finally set a goal for the theory: to do research without referring to transcendence. In this sense the theory of evolution is still Darwinian. Today the one is usually called neo-Darwinism, the term used for the first time probably by George Romanes in 1895. Roughly speaking it refers to Darwinian theory 
with no Lamarckism - this change in Darwinism had been done by August Weismann - Weismann barrier (Pigliucci 2007, 2744).

The theory of evolution is now distinct from Darwin's one if the new accomplishments are taken into account, like genetics, ecology, biochemistry, cybernetics and biophysics (Kuźnicki \& Urbanek 1970, 16). Ernst Mayr claims that today evolutionary biology incorporates so many new discoveries ("the concepts of mutation, variation, population, inheritance, isolation, and species were still rather nebulous in Darwin's day") that "is distinctly post-Darwinian" (Mayr 1966, 2). However, other authors argue that the theory of evolution today is Darwinian because there is no fundamental change in comparison to On the Origin of Species in terms of methodology and basic concepts (Kuźnicki \& Urbanek 1970, 15).

The theory of Darwin is based on "indefinite heredity that allows for open-ended evolution" (Day 2012, 626). What does it mean to understanding humanity? Perhaps the most crucial problem is how Darwin's theory applies to our spiritual side. John Lucas published a paper about machine-mind correlation that has enormous influence on perceiving the mind in context of Gödel's incompletness theorem. He has written that we cannot build a machine to be like the mind: "Gödel's theorem must apply to cybernetical machines, because it is of the essence of being a machine, that it should be a concrete instantiation of a formal system. It follows that given any machine which is consistent and capable of doing simple arithmetic, there is a formula which it is incapable of producing as being true - i.e., the formula is unprovable-in-the-system-but which we can see to be true. It follows that no machine can be a complete or adequate model of the mind, that minds are essentially different from machines" (Lucas 1961, 113). The mind can be treated as "machine" in the theory of evolution because it does not refere to tanscendental features of brain pointing to be the soul-like, at least in Darwin's interpretation. His theory can be incomplete in Gödel's sense. Bological evolution is part of cosmic one (Heller 2012, 274). ${ }^{1}$ By showing

1 Heller writes: "laws of physics, cosmological evolution and biological evolution - are closely related. [...] Biological evolution is only a fiber of cosmic evolution”. 
that physical theories are incompleted we can prove that Darwin's theory is incomplete too.

Gödel's incompletness theorem is applicable to the physial theories if they are large enough to enable self-referencing. This case happens when a theory "aspire to encompass the whole Universe, covering all the phenomena in Nature" (Ben-Ya'acov 2019, 4), because we observe the Universe being part of it, not from outside and this entails self-referencing and incompletness. Darwin's theory is all-encompassing regarding life's evolution. We are subject to the process of evolution and "self-referencing necessarily involves human consciousness" (Ibid., 6). It means that if the theory of evolution is not contradictory, then it is also incomplete and, as part of its own methodology, it will not tell us anything more about man. However, we see this more. There is a clear analogy with Lucas's argument regarding the machine-mind relationship. We see the truth about man, which Darwin's theory does not see, except that in evolution we do not use the term "machine" but "brain". Some human phenomena that we can see - and the theory does not - are: infinite desires. i.e. knowledge, justice and love, environmental protection or feeling of transcendence. They are unprovable-in-the-system but they are true and do not fit to the concept of evolution and struggle for survival (cf. Dawkins 1989, 7). Raymond Tallis says that "many aspects of everyday human consciousness elude neural reduction" (Tallis 2011, 2). Tallis claims that the mind cannot be reduced to "activity in individual brain-bits" (Ibid., 3) at least because then "free will would be an illusion" (Ibid.). Basing on Aquinas we can elucidate this problem. Mirosław Mróz explains: "Because of his nature man possesses a certain balance of the body and due to it no powers of the soul have an excessive domination over others. It is different with animals, because they are not free but determined and do not act in accordance with virtues only according to their habits" (Mróz 2018, 123). The soul-body unity plays a key role to understand human phenomena that are not fully encapsulated within the theory of evolution. If the soul exists, we cannot change the human nature. By manipulating in the body we will not redefine human being because what makes us humans lies in connection of these two elements. 
The soul as non-material being is independent on changes in the body. In that case transhumanism could not enhance human nature.

Transhumanism, despite being part of broadly understood science, put itself in the place of philosophy by making several philosophical assumptions:

1) First one is that the humanity is limited to body;

2) According to the following steps: humans $\rightarrow$ transhumans $\rightarrow$ posthumans, transhumanists claim that a new society might be created based on the new technologies. What more, posthumans living in such society will live in peace and will develop in infinity.

Because these assumptions relate to philosophical considerations, let us rethink the arguments given above from philosophical viewpoint.

\section{Cryonics}

The first theorem is that humanity is realized within the body's confines. To make transhumanism real, to implement its purposes into life, transhumanists develop such ideas as: grinding/biohacking, anti-aging and anti-death movement, technogaianism, singuliatarianism. All these concepts regard to the extended life on Earth, perhaps eternal life. While the first problem can be treated as a slight interference in our bodies, anti-aging and anti-death movement is much more serious. It can be said that if we exclude death, it will entail the lack of reproduction of human race. It is called cryonics. As we can read on the website of Alcor Life Extention Foundation, "cryonics is an effort to save lives by using temperatures so cold that a person beyond help by today's medicine can be preserved for decades or centuries until a future medical technology can restore that person to full health" (Alcor 2019a). How it is possible that after decades or centuries a person will be restored to life? Alcor Foundation indicates that the central point to revive a human being is to save "a particular structure of matter. Life can be stopped and restarted if cell structure and chemistry are preserved sufficiently well” (Ibid.). Thomas Donaldson advocated for cryonics saying that it is going to be possible to prolong our lives to "immortalilty". The number given by him are as follows: 
- "complete elimination of aging would imply an average lifespan of about 600 years;

- "A rough estimate of the length of time someone may expect to live before his body is totally destroyed by accident is about 100,000 years";

- "A reduction of the accident to $1 / 10$ its present value, for instance, would imply, on these figures, an average longevity of 1,000,000 years".

It is said that by technological manipulations in human body we can prolong its life actually any amount of time. So, philosophical background of thinking about a human being as composition of atoms we can tamper with them belongs to - broadly speaking - materialism. Moreover, supporters of cryonics argue that our identity after a legal death will be restored as well: "If cryonics patients must be legally dead before they are cryopreserved, and if once cryopreserved all metabolism has irreversibly (for the present) ceased, then are not cryopreserved patients, at least in some limited sense, dead? The answer is no" (Wowk 1988, in: Alcor). A study of Natasha Vita-More and Daniel Barranco shows possibility of memory preservation after vitrification (Vita-More 2015, 458). Admittedly, the study was conducted on warms but it is promising for cryonic-supporters that the same could be done to humans.

I think that the above example testifies that a human is seen as material-based being. Although, Alcor claims that cryonics is in accordance with Christianity and other religions. This is because cryonics does not want to be perceived as a tool for resurrection from the dead but it is rather like stopping the process od passing away and - after decades of centuries a patient will be under the influence of reverse process. A patient did not die. The question is: what about the soul? Christians believe in having the immortal soul. Death means that the soul separates from the body (STh I, q. 89 , a. 1). What does it mean to the soul when a patient is cryopreserved? On question: "What happens to the souls of people in cryopreservation?", the answer is: "If the premise that patients cryopreserved today are not dead is accepted, then the soul of a cryonics patient is in the same condition as the soul of a frozen human embryo or the soul of a person who is in a coma or 
unconscious" (Alcor 2019b). It seems that such statement is in accordance with Aquinas doctrine about the soul being present in each part of the body (STh, I, q. 76, a. 8). ${ }^{2}$ Even if not the whole body is vitrified but only the brain, it does not matter because the soul of a person exists as the whole being in each part, that is in the brain as well.

Perhaps the most important question that can be asked is as follows: "Why should Christians, who know their eternal home is Heaven, desire to remain alive physically on Earth?” (Alcor 2019b). Alcor's answer is like that: God does not want people to suffer and die, so our efforts to eliminate sickness from life and to prolong our existence on Earth are good. According to Alcor such attitude has been demonstrated in many places in Bible, both in the Old and New Testament (Ibid.). Maybe the best examples are Jesus' miracles. Christ had been taking suffering and illnesses from persons he met. The question is why Jesus had been doing it? If we agree with Alcor we will concede that the goal was to remove suffering. Taking into account that Jesus raised from the dead Lazarus of Bethany, it could be concluded that the ultimate purpose of Christ was to eliminate death - in the sense of the soul's separation from body.

Transhumanism is accord with spirituality. Transhumanistic approach to spiritual dimensions of human's life, Trans-Spirit, "assumes that physical, physiological and psychological explanations are preferable to non-physical, mystical and supernatural ones" (LaTorra 2005, 42). And, if it is an approach that enhance the importance of "science and technology, and the aim of overcoming hindrances to human well-being" (Ibid.), isomuch "this approach precludes the acceptance of many traditional religious beliefs" (Ibid.). Spirituality here is focused on removeing suffering that is not treated as the value and on "personal transformation and blessed happiness, and then share them with others" (Ibid.). In accordance with this approach to spirituality Alcor interprets Jesus' miracles.

In the light of Biblical Thomism we can interpret Jesus' miracles. Biblical Thomism "seeks to understand and employ the praxis of sacra doctrina, as

2 The difference between soul and body is connected with the doctrine of hylomorphism. More details on hylomorphism you can find here: Manning 2013, 177-181. 
exemplified primarily by Thomas Aquinas, and the pivotal role of Scripture in such a speculative engagement with Revelation as a way to overcome modern separations” (Roszak and Vijgen 2018, 14; cf. Roszak 2016, 123-125). Aquinas' attitude to the Bible is not separated from his Summa Theologiae. "His deeper penetration of certain passages from Scripture leads Aquinas to develop his thought" (Roszak and Vijgen 2018, 16). According to Thomas "for perfect happiness the intellect needs to reach the very Essence of the First Cause. And thus it will have its perfection through union with God as with that object, in which alone man's happiness consists" (STh, I-II, q. 3, a. 8.). We can conclude that to Thomas union with God is the greatest happiness for man and to be unified with God we have to die and go to Heaven. This is different approach to happiness than the one did by transhumanists. Aquinas interprets also Jesus' miracles differently.

There are two reasons for miracles: 1) "confirmation of the doctrine that a man teaches" and 2) "in order to make known God's presence in a man by the grace of the Holy Ghost" (STh, III, q. 43, a. 1). These reasons are met in Christ: by working miracles he was confirming the truth he was teaching and the ones were testifying to God's presence in Jesus (Ibid.). In Christ the Kingdom of God came to Earth and in this sense this world has become a better place what is in accordance with transhumanism. But if the greatest happiness to man is to be unified with God, Jesus' teaching is about another reality (cf. Poytheress 2016, 26-27; Dodd 1935, 38; cf. Paciorek 2012, 25-26).

We see that the attitude to human nature of transhumanism is under the influence of Darwin's theory, even when it tries to combine the naturalistic viewpoint with religious one including the concept of soul. As it was said, the theory of evolution is right wihtin the confines of naturalistic paradigm. But it seems to be incompleted if the point is some human phenomena like aforementioned.

Even if medicine will be so developed to revive vitrified patients, the whole idea of transhumanism is rather Utopia. Behind this statement there is transhumanistic assumption that the new technologies will be available for all people. We tell about the future society with excluding nobody. The 
scenario of implementing transhumanism would be realized in two different ways. The first one relies on giving to each person on Earth the access to technologies allowing to become posthuman. But it is very unlikely because in history we do not find examples when one country having technological advantage over the other ones would like to share own accomplishments and to loose strategical supremacy. If such technology would be given, the second option could be realized, that is to give it to chosen societies beginning with our country. It entails billions of people being left behind. It is worth to add that the chosen people who will skip to posthuministic society will be the last generation on Earth, because if ideas of transhumanism are fully implemented, like lack of getting old and death, to avoid overpopulation the posthumans will not be allowed to have their own children. Roughly speaking, the poshumans will be the last "human beings" living forever on Earth.

Looking back at history of philosophy we can see that the situation we will have to face with the arrival of technology making transhumanistic idea real, has been happened already. In his work Thus Spoke Zarathustra Friedrich Nietzsche wrote: "I teach you the overman. Man is something that shall be overcome. What have you done to overcome him?" (Nietsche 1954,124). The term Übermensch is not compatible with transhumanistic posthuman for Two reasons (Merlo 2019, 54-57): 1) "the closeness of the overman to the earth” (Ibid., 54), 2) “death figures massively into Zarathustra's portrayal of the overman" while "goals of the transhumanists is to avoid death" (Ibid., 56). However, it is worth to notice that using technology to create posthumans and at the same time having people being beyond of these technological achivements will divide mankind again. And this is a common feature between Übermensch and posthuman: creating a division and this might trigger another conflict.

\section{The mind and soul}

Before we are going to present a possibility of mind uploading we have to see what is the mind and the soul and what kind of interaction is between 
them. Terminology related to the soul goes back to Homer's works. The most

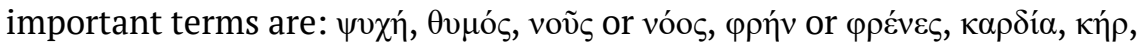
ท̃ $\tau o \rho$ (Furley 1956, 2). These concepts regard basically the "things happening to the body" (Ibid.). As time passed the terms took on a new meaning going

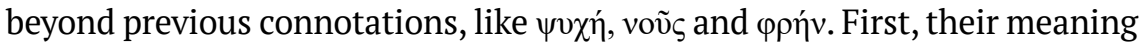
was like a description what is going on in a body and then changed into more spiritual meaning. How Furley says, "Psyche, thymos and noos are sometimes siad in the Homeric poems to reside in the body [...]" (Ibid., 3). Noos changed the meaning to "understanding", "appreciation" and "thinking" (Ibid.). Philosophical turn into non-materialistic view on what we call the soul did Plato. The soul is independent on body and should exist without it.

Later developement of the concept of soul was mainly under the influecne of Christianity. Church's Councils were defending immortality of soul and its self-existence. One of the best example is the Council of Vienne and I accept its descripion of the soul in this article. The Council declares: "we define that anyone who presumes henceforth to assert defend or hold stubbornly that the rational or intellectual soul is not the form of the human body of itself and essentially, is to be considered a heretic" (Concilium Viennensis, 361). This approach to the human soul denotes that it is a form and entails direct animation, i.e. God creates each soul of a particular human being. The soul is intellectual being what is the reference to the history of concept. That is why the soul can be seen as $\psi v \chi \eta \dot{\eta}$, voũ or $\varphi \rho \eta$ v but with changed meaning. Unity between the soul and the body is called dyadic unity (Bartnik 2009, 407). This unity is composite - unum compositum and both elements of a human being are incomplete - anima substantia incompleta (Ibid., 408). Presented approach to the concept of soul excludes the following solutions of relations between soul and body: anthropological monism, extreme duality, Manichaeism, anima communis, Cartesian dualsim, emipiricism and sensuality, modern idealistic monism, materialistic psychicism (Ibid., 413).

If the point is the mind basically there are two ways of looking at it: biological theories and psychological ones: "biological theories of identity hold that survival of a person requires intact survival of a brain or a biological 
organism. Psychological theories of identity hold that survival of a person requires the right sort of psychological continuity over time (preservation of memories, causally related mental states, and so on)" (Chalmers 2010, 41-42).

These two theories split into two kinds of argumentation of what the mind is. The first one can be totally dependent on brain and then it could be interpreted as an upper structure of the brain existing as long as brain. But it can be seen as an independent entity in psychological theories. Today, because of the naturalistic paradigm, the mind is seen as entity being emerged from brain.

\section{Mind uploading - is it possible?}

The last problem I want to discuss is mind uploading (whole brain emulation/WBE, brain upload, mind transfer). The idea relies on assumption that a mind emerges from brain as a new quality being something more than simple sum of particles from which the mind comes from. This problem is related to a body-mind problem initiated by René Descartes (Descartes, II, 8). However, in Descartes' times the soul was perceived as entity being created by God. Today, because of the naturalistic paradigm, the mind is seen as entity being emerged from brain. This is physicalism: "mental states are states of the body" (Nagel 1974, 446). Such attitude does not make the body-mind problem easier to solve (McGinn 1989, 349-350). ${ }^{3}$ Still, we do not know what the mind is. We can rather observe how it works. Thus, functionalism. The mind being treated as software supervening over brain - hardware, is strictly connected with the brain but it is not one itself. The change that it can be seen in comparison to Descartes' contribution to the problem relies on a shift being made from the soul - spiritual being created by God, to mind - something what we have coming from the brain.

3 The reason why McGinn says the problem unsolvable is that "[...] we are cut off by our very cognitive constitution from acheiving a conception of that natural property of the brain (or of consciousness) that accounts for the psychophysical link” (p. 350). 
No matter in what kind of device the mind is uploaded because its content is the same. It entails so called multiple realizability, the problem - like the others - unresolved (Gillet 2003, 592-593, 603). Despite the multiple realizability is still uncertain wanting to give the ultimate answer, one might to figure it out as a book analogy (Hauskeller 2012, 191-193). Having a copy of book, we are going to tend to say that we have that book or rather that it is only a copy? Comparig this example with biological and psychological theories, a strong division between brain and mind corresponds to an original and duplicate in book's example. If we say that the most important is to preserve contents of a book without paying attention to an original thing in psychological sense, a physical medium of information does not matter.

It seems that only psychological interpretation enables the mind uploading. The assumption is that the mind contains informations but - not knowing what the mind is - they might be downloaded from the brain's neurons. In connection with these three possibilieties shall be considered (Chalmers 2010, 34):

1) destructive uploading;

2) nondestructive uploading;

3) gradual uploading.

The first option says that with uploading the neurons are going to be destroyed: "Here one freezes a brain, and proceeds to analyze its structure layer-by-layer. In each layer one records the distribution of neurons and other relevant components, along with the character of their interconnections. One then loads all this information into a computer model that includes an accurate simulation of neural behavior and dynamics. The result might be an emulation of the original brain" (Ibid.). Nondestructive uploading is now not available because of lack of technology: "The holy grail here is some sort of noninvasive method of brain imaging, analogous to functional magnetic resonance imaging but with fine enough grain that neural and synaptic dynamics can be recorded" (Ibid.). Development of nanotechnology gives hope to insert nanorobots into the brain and to transmit the information to a computer: 
Here one or more nanotechnology devices (perhaps tiny robots) are inserted into the brain and attach themselves to a single neuron. Each device learns to simulate the behavior of the associated neuron and also learns about its connectivity. Once it simulates the neuron's behavior well enough, it takes the place of the original neuron, perhaps leaving receptors and effectors in place and offloading the relevant processing to a computer via radio transmitters. It then moves to other neurons and repeats the procedure, until eventually every neuron has been replaced by an emulation, and perhaps all processing has been offloaded to a computer (Ibid.).

Let us assume that some sort of uploading is possible. Then a few important questions must be answered. For example, who/what is the uploaded mind? Is it me or only mine? If mind uploading can instantiate another me, then a question about my identity and consciousness raises. If I am doubled, my second me shall have the same rights and so on. Roughly speaking, if we agree with a statement that uploaded mind is second me, then my digital mind will be a person. Metaphysics is helpful in finding the solution.

First principles allows to investigate metaphysical status of mind uploading or - briefly - what exactly is the uploaded mind? The law of identity states that for all $x: x=x$. In our case it means that me $=$ me in this sense like I am now. I identify with myself right now and it cannot be another me, duplicated. According to the law of excluded middle $P v \sim P$, it is impossible to realize a situation when there are two minds in different states. This law says that the mind can exist as a part of brain or in a computer, tertium non datur. Finally, the principle of non-contradiction $\sim(P \wedge \sim P)$ teaches that no being can be and not to be true in the same time. In other words the law of non-contradiction asserts that if the mind coexists with brain and that we understand the mind in this way, the one cannot be separated from brain by uploading into computer, because then the same being would exist in two manners in the same moment. The law of sufficient reason might be also added, since it says that there is basically one reason for the mind: brain or God. The naturalistic paradigm has chosen the brain because referring to God and, consequently, to the soul reminds an argument called God of the gaps. The argument is related to the theory of evolution, that is the 
evolutionists rejct God of the gaps argument stating that it is Bible-based view with connection to creationism (Pennock 2007, 310). Methodological naturalism does not rule out God but delimits referring to him assuming that "there is an account of the world that does not require supernatural intervention that can be accessed by scientific means" (Mitchell 2001, 333).

Doctor Angelicus claims that as long as the soul is connected with body must use imagination to cognize (STh, I, q. 89, a. 1). He says that this difficulty would be easier to solve from Platonic viewpoint but Aquinas believes that it is better for the soul to coexist with body (Ibid.) and here is very important text from Summa Theologiae about the nature of cognition: "But if we admit that the nature of the soul requires it to understand by turning to the phantasms, it will seem, since death does not change its nature, that it can then naturally understand nothing; as the phantasms are wanting to which it may turn" (STh, I, q. 89, a. 1). Because of its nature the soul uses body's senses to cognize and without the body soul could not cognize. In the soul intellectual properties can be found (STh, I, q. 79, a. 1). The same ones which are put today in the mind. Aquinas admits that the soul being separated from body can still cognize the spiritual substances. While being united with the body soul "has a mode of understanding, by turning to corporeal phantasms, which are in corporeal organs" (Ibid.).

In view of the above we can try to answer the question: what is the mind? It is a way of cognition rather then "being”. The mind is neither a part of the body nor the soul. It is a mode of understanding of a human being having two united elements in oneself. The mind is a product of body-soul's connection. This connection instantiates the mind and the one disappears when the soul leaves the body.

If we accept above solution, mind uploading will be possible to realize but it will not be a person. It should be understood rather as a scan of the brain, all informations being copied into a computer, my preserved memory being kept in a computer just in case to cure my - among others - future diseases etc. The future generations will be able to read in our memories and to understand our mindsets in the past times from their perspective. But a human being is something more than only the mind's contents. 


\section{Conclusion}

The foregoing discussion shows that transhumanism is partially workable because it can preserve our bodies and thereby save us from death by stopping the process of dying and reversing it in the future; it can save our minds form potential damages by uploading their contents into computers and by the same token make incurable diseases being curable; it can also help to develop strong artificial intelligence and to raise the level of social development. But all of these points to the fact that transhumanism will not be fully accomplished.

The first reason of impossibility of transhumanism's implementation fully is that the theory of evolution seems to be insufficient to encapsulate a human being in all aspects and in whole complexity. The second one is the assumption that all people will have equal access to the latest technologies changing them into transhumans and posthumans. It is probable impossible (because of political reasons among others) and would divide societies into better ones and worse and this could lead to war. Finally, mind uploading even if possible to realize, it will not duplicate a person's identity and consciousness. Uploaded mind will not be a person but rather their brain scanned neuron by neuron. To sum up, we can answer for the title question: transhumanism is heading towards Utopia. It does not rule out that can contribute to the development of new technologies and raise the level our lives.

\section{References}

Alcor Life Extension Foundation. In: https://alcor.org/AboutCryonics/index.html. Accessed December 23, 2019.

Alcor Life Extension Foundation. In: https://alcor.org/Library/html/christianityandcryonics.html. Accessed December 25, 2019.

Aquinas, Thomas. 1882. Summa Theoogiae I. Roma: Commissio Leonina. Asla, Mariano. 2019. "On the limits, imperfections and evils of the human condition. Biological improvement from a thomistic perspective.” Scientia et Fides 7(2): 77-95. DOI: http://dx.doi.org/10.12775/SetF.2019.017. 
Bartnik, Czesław. 2009. Dogmatyka katolicka. Lublin: KUL.

Ben-Ya'acov, Uri. 2019. “Gödel's incompleteness theorem and Universal physical theories." Journal of Physics: Conference Series 1391: 1-9.

Chalmers, David J. 2010. “The Singularity: A Philosophical Analysis.” Journal of Consciousness Studies 17: 7-65.

Concilium Viennensis. 1990. Decretum 1. In Decrees of the ecumenical councils, edited by Norman P. Tanner, et al., London: Sheed and Ward; Washington (D.C.): Georgetown University Press.

Dawkins, Richard. 1989. The Selfish Gene. Oxford: Oxford University Press.

Day, Troy. 2012. “Computability, Gödel's incompleteness theorem, and an inherent limit on the predictability of evolution.” J. R. Soc. Interface 9: 624-39.

Descartes, Réne. Meditations on First Philosophy, In http://www.classicallibrary.org/ descartes/meditations/5.htm. Accessed May 25, 2020.

Dodd, Charles H. 1935. Parables of the Kingdom. London: Nisbet.

Donaldson, Thomas. 1976. “A Brief Scientific Introduction to Cryonics.” In https:// alcor.org/Library/html/DonaldsonBrief.html. Accessed December 25, 2019.

Furley, J. David. 1956 “The Early History of The Concept of Soul.” Bulletin of the Institute of Classical Studies 3/1: 1-18.

Gillet, Carl. 2003. “The Metaphysics of Realization, Multipe Realizability and the Special Sciences.” The Journal of Philosophy: 591-603.

Glickman, Stephen E. 2009. "Charles Darwin, Alfred Russel Wallace, and the Evolution Creation of the Human Brain And Mind.” Gayana 73: 32-41.

Hauskeller, Michael. 2012. "My Brain, My Mind, And I: Some Philosophical Assumptions of Mind-uploading.” International Journal of Machine Consciousness: 4/1: 187-200.

Heller, Michał. 2012. Filozofia przypadku. Kosmiczna fuga z preludium i coda. Kraków: Copernicus Center Press.

Kuźnicki, Leszek \& Adam Urbanek. 1970. Zasady nauki o ewolucji. T. II. Warszawa: Państwowe Wydawnictwo Naukowe.

LaTorra, Michael. 2005. “Trans-Spirit: Religion, Spirituality and Transhumanism.” Journal of Evolution \& Technology 15: 41-55.

Lucas, John. 1961. “Minds, Machines and Gödel.” Philosophy XXXVI: 112-27.

Manning, Gideon. 2013. “The History of 'Hylomorphism.” Journal of the History of Ideas 74/2: 173-187.

Mayr, Ernst. 1966. Animal Species and Evolution. Cambridge: Harvard University Press. McGinn, Colin. 1989. “Can we solve the Mind-Body Problem?” Mind, New Series 98/391: 349-366. 
Merlo, Joshua. 2019. "Zarathustra and Transhumanism. Man is Something to Be Overcome.” Scientia et Fides 7(2): 41-61. DOI: http://dx.doi.org/10.12775/ SetF.2019.015.

Mitchell S. D. 2001. Comment on Pennock's Tower of Babel Paper read at Association for Informal Logic and Critical Thinking (AILACT). American Philosophical_Association Conference, Atlanta.

Moore, Max. 2009. A Letter to Mother Nature: Amendments to the Human Constitution. In: http://strategicphilosophy.blogspot.com/2009/05/its-about-ten-years-sincei-wrote.html. Accessed December 07, 2019.

Mróz, Mirosław. 2018. "Physiological and Psychological Foundation of Virtues: Thomas Aquinas and Modern Challenges of Neurobiology.” Scientia et Fides 6(2): 115-128. DOI: http://dx.doi.org/10.12775/SetF.2018.019.

Nagel, Thomas. 1974. “What Is Like to Be a Bat?” The Philosophical Review 83(4): 435-450.

Nietsche, Fridriech. 1954. Thus spoke Zarathustra, transl. Walter Kaufmann. New York: Viking Press.

Paciorek, Antoni. 2012. Przypowieści Jezusa. Wprowadzenie i objaśnienie. Warszawa: Edycja.

Pennock, Robert T. 2007. God of the gaps: The argument from ignorance and the limits of methodological naturalism. In: Scientists Confront Intelligent Design and Creationism edited by Petto, Andrew J., and Laurie. R. Godfrey, 309-338. Norton: New York.

Pigliucci, Massimo. 2007. “Do We Need An Extended Evolutionary Synthesis?” Evolution 61(12): 2743-2749.

Poytheress, Vern S. 2016. The Miracles of Jesus. How the Savior's Mighty Acts Serve as Signs of Redemption. Wheaton: Crossway.

Roszak, Piotr. 2016. “Tomizm biblijny: metoda i perspektywy.” Biblica et Patristica Thoruniensia 9(3): 119-132. DOI: http://dx.doi.org/10.12775/BPTh.2016.024.

Roszak, Piotr \& Jörgen Vijgen, ed. 2018. Towards a Biblical Thomism. Thomas Aquinas and the Renewal of Biblical Theology. Pamplona: Eunsa.

Tallis, Raymond. 2011. "Rethinking Thinking.” The Wall Sreet Journal 12: 1-4.

Wallace, Alfred. 1869. "Sir Charles Lyell on Geological Climates and the Origin of Species” [Reviews of Principles of Geology (10 ${ }^{\text {th }}$ ed.)]. Quarterly Review 126: 359-94.

Wowk, Brian. 1988. “The Death of Death in Cryonics.” In: https://alcor.org/Library/ html/deathofdeath.html. Accessed December 25, 2019.

Vita-More, Natasha \& Daniel Barranco. 2015. “Persistence of Long-Term Memory in Vitrified and Revived.” Caenorhabditis elegans, Rejuvenation Research 18: 458-463. 